\title{
Journal of Scientometric Research: Affiliation and support system
}

\author{
Dr. M Ahmed, Ph.D \\ Managing Editor, SciBiolMed.Org \\ Vatika Business Centre, Divyasree Chambers, 2nd Floor, Wing A, 11, O’Shaugnessy Road, Langford Town, Bangalore 560025
}

Journal of Scientometric Research (JSCIRES) is an internationally targeted official publication of SciBiolMed.Org. It also receives support from Pharmacognosy Network Worldwide and INPHARM Association. The second issue onwards i.e. from January 2013 will be published with Medknow (www.medknow.com) which is now merged with Wolters Kluwer's Health.

\section{SCIBIOLMED.ORG}

ScibiolMed.Org is a non-profit private organization having its office located at Bangalore, India. SciBiolMed is dedicated to publish research in the field of science, biology and medicine. Their main mission is to enable those who seek the relevant research information on science, biology and medicine and make them available in different formats to suit their individual needs. A long term objective is to provide high quality, accurate and required information to enhance research and innovative concepts in scholarly publishing.

\section{Journals being Published by ScibiolMed}

This organisation is involved in publishing eight journals including JSCIRES. All the journals are peer reviewed, publish original, innovative and novel research articles. All the six established journals are indexed with major databases such as EBSCO, PubMed, SCOPUS, and Chemical Abstract. The brief highlights of these journals are given below.

*Corresponding author.

Dr. M Ahmed

Vatika Business Centre, Divyasree Chambers,

2nd Floor, Wing A, 11, O'Shaugnessy Road, Langford Town,

Bangalore 560025

E-mail: journals@scibiolmed.org www.scibiolmed.org

DOI: 10.5530/jscires.2012.1.3

\section{JOURNAL OF CARDIOVASCULAR DISEASE RESEARCH (www.jcdronline.com)}

Journal of Cardiovascular Disease Research is a circulating professional journal led by a group of research scientists, vascular disease experts and cardiologists coming from North America, Asia and Europe etc. Journal is being published quarterly. The journal is indexed in many abstracting services includes Chemical Abstracts, EBSCO Publishing's Electronic Databases, PubMed, SCOPUS, Ulrich's International Periodical Directory.

\section{JOURNAL OF PHARMACEUTICAL NEGATIVE RESULTS (www.pnrjournal.com)}

Journal of Pharmaceutical Negative Results is published semi-annually and brings out theoretical and empirical papers that report the negative findings and research failures in pharmaceutical field. The journal is indexed by many databases includes Caspur, Chemical Abstracts, EBSCO Publishing's Electronic Databases, SCOPUS, Ulrich's International Periodical Directory.

\section{INTERNATIONAL JOURNAL OF MEDICINE AND PUBLIC HEALTH (www.ijmedph.org)}

IJMEDPH focuses on internal medicine and publishes articles which promote medical science and public health. It is published bi-monthly and is indexed with Google Scholar, Directory of Open Access Journals, Genamics and Journalseek, Index Copernicus, Chemical Abstracts, Open J-Gate, SciAccess, Ulrich's periodical Directory.

\section{FREE RADICALS AND ANTIOXIDANTS (www.antiox.org)}

Free Radicals and Antioxidants is published quarterly and brings out articles in the field of free radicals and antioxidant biology. The journal aims to further research into the 
physiological, pathobiological, functional and therapeutic implications and applications of free radical biology and antioxidant agents. The journal is indexed with Google Scholar, Directory of Open Access Journals, Genamics and Journalseek, Index Copernicus, Chemical Abstracts, Open J-Gate, SciAccess, Ulrich's periodical Directory.

\section{JOURNAL OF NATURAL SCIENCE, BIOLOGY AND MEDICINE (www.jnsbm.org)}

Journal of Natural Science, Biology is published semiannually and serves the need of scientific and non-scientific personals involved/interested in Natural Science (Physics, Chemistry, Electronics, Mathematics, Astronomy, Oceanography, Engineering), Social Science, Economics, Biology and Medicine. The journal is indexed with Chemical Abstracts, EBSCO Publishing's Electronic Databases, PubMed, Ulrich's International Periodical Directory.

\section{JOURNAL OF CONTRADICTING RESULTS IN SCIENCE (www.jcrsci.org)}

Journal of Contradicting Results in Science is published annually and theoretical and empirical papers that report the contradictory findings and research failures in scientific field. Launching issue is available online.

\section{JOURNAL OF SCIENTOMETRIC RESEARCH (www.jscires.org)}

Journal of Scientometric Research is an internationally targeted publication of SciBiolMed.Org. It encourages both empirical and theoretical contributions that advance scientometric research and would also reach out to scholars of Science and Technology Studies (STS), sociology, economics and any other field who use scientometric data as the 'object of investigation' or apply scientometric analysis in policy or innovation studies. Journal is being published triennially i.e. three issues in a year (January-April, May-August, September-December).

\section{ONCOLOGY, GASTROENTEROLOGY AND HEPATOLOGY REPORTS (www.oghreports.org)}

Oncology, Gastroenterology and Hepatology Reports aims to explore the areas of Cancer research and gastrointestinal tract including the liver. The journal is envisioned as a platform for basic and translational researchers, clinicians and students to publish their research, review articles and case reports. It will be launching first issue soon.

\section{PHARMACOGNOSY NETWORK WORLDWIDE}

Pharmacognosy Network Worldwide [PHCOG.NET] is a non-profit network dedicated to Natural Products Research to develop promising drugs. Main mission is to make information on herbal drug research readily available in different formats to suit the individual needs of anyone who wants it. A long term objective is to provide high quality, accurate, and necessary information to enhance herbal drug research.

\section{Journals Published by PHCOG.NET}

Seven journals are published by this organisation. All the journals are peer reviewed, publish original, innovative and novel research articles and are indexed with major databases such as EBSCO, PubMed, SCOPUS, and Chemical Abstract.

- Pharmacognosy Magazine (www.phcog.com)

- Pharmacognosy Research (www.phcogres.com)

- Pharmacognosy Reviews (www.phcogrev.com)

- Pharmacognosy Journal (www.phcogj.com)

- Pharmacognosy Communications (www.phcogcommn.org)

- Journal of Natural Pharmaceuticals (www.jnatpharm.org)

- Unani Research (www.unanires.org)

\section{INPHARM ASSOCIATION}

The InPharm Association is a scientific and educational society founded in 2003. For last 10 years, InPharm has contributed in different ways to the advancement of Pharmacy. The InPharm promotes discussion among its members and with scholars in related fields, in part through the activities of its affiliated groups.

This association publishes five journals. All the journals are peer reviewed, publish original, innovative and novel research articles and are indexed with major databases such as EBSCO, PubMed, SCOPUS, Chemical Abstract.

\section{Journals Published by InPharam}

- Journal of Young Pharmacists (www.jyoungpharm.in)

- Systematic Reviews in Pharmacy (www.sysrevpharm.org)

- Journal of Pharmacology \& Pharmacotherapeutics (www.jpharmacol.com)

- Pharmaceutical Methods (www.phmethods.org)

- International Journal of Pharmaceutical Investigation (www.jpionline.org) 